\title{
Karakteristik Probiotik Minuman Fermentasi Laktat Sari Buah Nanas dengan Variasi Jenis Bakteri Asam Laktat
}

\section{Probiotic Characteristic of Lactic Fermentation Beverage of Pineapple Juice with Variation of Lactic Acid Bacteria (LAB) Types}

\author{
Samsul Rizal ${ }^{1}$, Maria Erna ${ }^{1}$, Fibra Nurainy ${ }^{1}$, dan Artha Regina Tambunan ${ }^{1}$, \\ ${ }^{1}$ Jurusan Teknologi Hasil Pertanian Fakultas Pertanian Universitas Lampung \\ J1. Prof. Soemantri Brojonegoro No. 1 Bandar Lampung, Lampung, Indonesia, 35145 \\ Corresponding author: marrizal@yahoo.com
}

\begin{tabular}{l} 
A R T I C L E IN F O \\
\hline Article history \\
Received date : 11 February 2016 \\
Revised date : 9 May 2016 \\
Accepted date :10 June 2016 \\
Available online at: \\
http://kimia.lipi.go.id/inajac/index.php \\
\hline Kata kunci: \\
Probiotik \\
Aktivitas antimikroba \\
Bakteri asam laktat \\
Minuman sari buah nanas \\
Keywords: \\
probiotic, antagonistic activity, lactic \\
acid bacteria, pineapple juice \\
beverages
\end{tabular}

\begin{abstract}
Abstrak
Pangan fungsional adalah pangan yang dikonsumsi sebagai diet biasa, memiliki efek fisiologis, dan dapat mengurangi efek dari penyakit kronis. Salah satunya adalah minuman probiotik. Minuman probiotik yang telah dikenal secara luas selama ini diproduksi dengan menggunakan susu sapi sehingga relatif mahal harganya. Penggunaan bahan baku alternatif seperti sari buah nanas diperlukan untuk menghasilkan produk minuman probiotik yang lebih terjangkau namun memiliki kualitas yang baik. Tujuan dari penelitian ini adalah untuk mempelajari pengaruh jenis Bakteri Asam Laktat (BAL) terhadap karakteristik minuman probiotik sari buah nanas, dan mendapatkan jenis BAL terbaik yang menghasilkan karakteristik probiotik terbaik dari minuman fermentasi laktat sari buah nanas. Penelitian ini menggunakan metode eksploratif dalam perlakuan tunggal jenis BAL: Lactobacillus acidophilus, Lactobacillus bulgaricus, Lactobacillus casei, dan Streptococcus thermophilus sebagai inokulum uji. Data yang diperoleh dianalisis dengan menggunakan Beda Nyata Terkecil pada 1\% dan 5\%. Perlakuan yang diamati adalah nilai $\mathrm{pH}$, asam laktat total, jumlah BAL, ketahanan terhadap $\mathrm{pH}$ asam $(2,5)$, dan uji aktivitas antagonis terhadap bakteri patogen. Hasil penelitian menunjukkan bahwa strain terbaik yang menghasilkan minuman probiotik yang memenuhi syarat sebagai kriteria probiotik adalah Lactobacillus casei. Minuman probiotik yang dihasilkan oleh Lactobacillus casei memiliki nilai $\mathrm{pH} 3,54$; total asam laktat 3,45; dan jumlah BAL $1,1 \times 10^{10} \mathrm{cfu} / \mathrm{mL}$, selisih antara $\log$ jumlah koloni pada $\mathrm{pH}$ asam dan kontrol adalah 5,67 cfu/mL; dan aktivitas antagonis terhadap bakteri patogen Bacillus cereus adalah 13,97 mm2 (tertinggi).
\end{abstract}

\begin{abstract}
Functional foods, is food that consumed as usual diet, has physiological effect, and can reduce the effect of chronic disease. One of them is probiotic beverages. Probiotic beverages that have been widely known over the time were produced by dairy house. This product could have been expensive due to the cost of raw materials. The alternative raw material such as the use of extracted pineapple juice may reduce the price of the final product. The aim of this research was to study the effects of Lactic Acid Bacteria (LAB) types toward characteristics of the probiotic beverage from pineapple juice, and get the best LAB types that produce the best probiotic characteristics of lactic beverage fermentation from pineapple juice. This research applied explorative method in a single treatment which LAB types Lactobacillus acidophilus, Lactobacillus bulgaricus, Lactobacillus casei, and Streptococcus thermophilus as an innoculum evaluated. The data obtained were analyzed using Least Significance Difference (LSD) on 1\% and 5\% degree. The observed reseach were $p H$ value, total lactic acid, total LAB, resistancy towards acidic $p H(2,5)$ test, and antagonistic activities test against pathogenic bacteria. The result showed that the best strain qualified
\end{abstract}




\begin{abstract}
as probiotics criteria was Lactobacillus casei. It was having pH value 3,54; total lactic acid 3,45; and total Lactobacillus casei 1,1 $1 \times 10^{10} \mathrm{cfu} / \mathrm{mL}$. The log colony difference for the low acid-tolerant $\mathrm{pH}$ was 5,67 cfu/mL; and the antagonistic activity towards pathogen bacteria Bacillus cereus was 13,97 $\mathrm{mm}^{2}$.

(C) 2016 Indonesian Journal of Applied Chemistry. This is an open access article under the CC BY-NC-SA license.
\end{abstract}

\section{PENDAHULUAN}

Pangan fungsional, menurut Badan POM adalah pangan yang secara alamiah maupun telah mengalami proses, memiliki satu atau lebih senyawa yang berdasarkan kajian-kajian ilmiah dianggap memiliki fungsi-fungsi fisiologis tertentu yang bermanfaat bagi kesehatan. ${ }^{[1]}$ Salah satu produk pangan fungsional yang banyak dikonsumsi adalah minuman probiotik. Minuman probiotik adalah minuman yang mengandung bakteri seperti bakteri asam laktat (BAL) yang menguntungkan bagi saluran pencernaan karena dapat meningkatkan keseimbangan mikroflora usus dan mampu bertahan hidup dalam keasaman lambung sehingga dapat menempati usus dalam kuantitas yang cukup besar. Produk probiotik dapat menghambat bakteri patogen dan melakukan metabolisme terhadap laktosa sehingga bermanfaat bagi penderita intoleransi laktosa. ${ }^{[2]}$ Pertumbuhan bakteri patogen dapat ditekan oleh bakteri menguntungkan yang terdapat dalam minuman probiotik sehingga dapat menjaga keseimbangan mikroflora dalam usus. Gangguan saluran pencernaan seperti tipes, diare, dan disentri yang merupakan salah satu masalah penyakit yang sering dialami masyarakat Indonesia dapat dicegah dengan mengonsumsi minuman probiotik ini.

Minuman probiotik yang sudah dikenal luas oleh masyarakat selama ini diproduksi dari hasil fermentasi susu antara lain yogurt, susu asidofilus, bulgarian milk, kefir, kumiss, piima, skyr, taetee, leben dari Mesir, dahi dari India, hamao dari Asia Tengah, yakult, dan lain-lain ${ }^{[3]}$ sehingga harganya relatif lebih mahal. Untuk itu perlu digunakan bahan alternatif misalnya berbahan nabati sebagai bahan baku pembuatan minuman probiotik untuk memperoleh minumpan probiotik yang lebih terjangkau bagi masyarakat. Minuman probiotik berbahan dasar nabati yang sudah diteliti di antaranya minuman yoghurt dari sari kulit nanas, ${ }^{[4]}$ yoghurt sinbiotik dari ekstrak cincau hijau, ${ }^{[5]}$ minuman probiotik dari sari kurma, ${ }^{[6]}$ minuman probiotik buah naga merah, ${ }^{[7]}$ serta minuman probiotik dari sari buah nanas. ${ }^{[8]}$

Hasil penelitian tentang pembuatan minuman fermentasi laktat dari kulit nenas menunjukkan bahwa kulit nanas dapat dijadikan sebagai bahan baku alternatif pembuatan minuman yang berpotensi sebagai probiotik selain susu. ${ }^{[4]}$ Namun hasil penelitian tersebut belum memberikan informasi tentang kemampuan produk tersebut sebagai minuman probiotik. Selain itu, minuman fermentasi laktat dari kulit nanas yang dihasilkan memiliki kualitas organoleptik dan penerimaan keseluruhan yang kurang disukai. Pengembangan minuman fermentasi laktat dari buah nanas diharapkan dapat meningkatkan kualitas organoleptik minuman fermentasi laktat dan berpotensi sebagai produk probiotik yang baik bagi kesehatan tubuh. ${ }^{[8]}$ Dari pengembangan tersebut membuktikan bahwa buah nanas berpotensi sebagai bahan baku pembuatan minuman fermentasi laktat. Makalah ini dibatasi pada kajian sifat-sifat probiotik minuman fermentasi laktat dari buah nanas. Agar dapat dihasilkan minuman fermentasi laktat dengan sifat probiotik maka pada penelitian ini diteliti mengenai karakteristik probiotik minuman probiotik dari sari buah nanas dengan berbagai jenis BAL yang digunakan. Dari penelitian ini juga diharapkan dapat ditemukan jenis bakteri asam laktat (BAL) yang menghasilkan karakteristik minuman fermentasi laktat (probiotik) terbaik. Bakteri asam laktat yang digunakan meliputi Lactobacillus acidophilus, Lactobacillus bulgaricus, Lactobacillus casei, dan Streptococcus thermophilus. Oleh karena itu penelitian ini dilakukan untuk mendapatkan 
jenis BAL yang menghasilkan karakteristik minuman probiotik terbaik dan mengetahui karakteristik minuman fermentasi laktat sari buah nanas sebagai minuman probiotik.

\section{METODE}

Perlakuan disusun secara non faktorial dalam Rancangan Acak Kelompok (RAK) yaitu variasi dari kultur bakteri Lactobacillus acidophilus, Lactobacillus bulgaricus, Lactobacillus casei, dan Streptococcus thermophilus sebagai perlakuan tunggal dengan tiga kali ulangan. Data yang diperoleh diuji kesamaan ragamnya dengan uji Bartlett. Kemudian dianalisis dengan sidik ragam untuk mengetahui ada tidaknya pengaruh antar perlakuan. Data dianalisis lebih lanjut dengan uji lanjut Beda Nyata Terkecil (BNT) pada taraf $1 \%$ dan $5 \%$. Pengamatan yang dilakukan adalah uji potensi probiotik meliputi nilai $\mathrm{pH}$, total asam, total BAL), ketahanan terhadap asam, dan aktivitas antibakteri.

\subsection{Pelaksanaan Penelitian}

\subsubsection{Persiapan Starter}

Persiapan starter dilakukan dengan memodifikasi metode Nurainy, dkk (2013), yaitu kultur bakteri yang akan digunakan Lactobacillus acidophilus, Lactobacillus bulgaricus, Lactobacillus casei, dan Streptococcus thermophilus masing-masing dipindahkan dari kultur stok ke dalam tabung reaksi berisi media MRS Broth steril, selanjutnya diinkubasi menggunakan inkubator selama 24 jam pada suhu $37^{\circ} \mathrm{C}$. Kemudian sebanyak 40 L ditumbuhkan ke dalam susu skim 5\% (b/v) steril $10 \mathrm{~mL}$. Kultur ini disebut kultur induk. Selanjutnya dari kultur induk diinokulasikan ke dalam media susu skim (5\% $\mathrm{b} / \mathrm{v})$ dan glukosa $(3 \% \mathrm{~b} / \mathrm{v})$ dalam media nanas $50 \mathrm{~mL}$, dan diinkubasi selama 48 jam sehingga didapat kultur antara. Kemudian kultur antara diinokulasikan sebanyak 4\% (v/v) ke dalam media susu skim $5 \%(\mathrm{~b} / \mathrm{v})$ dengan penambahan $3 \%(\mathrm{~b} / \mathrm{v})$ glukosa steril dalam media nanas 50 ml. Inkubasi dilakukan selama 48 jam pada suhu $37^{\circ} \mathrm{C}$, sehingga didapatkan kultur kerja.

\subsubsection{Pembuatan Minuman Fermentasi Laktat dari Sari Buah Nanas}

Buah nanas yang dipilih ialah buah nanas madu varietas Queen yang cukup matang, berwarna kuning oranye, dan layak dikonsumsi. Buah nanas mula-mula dikupas kulitnya dan dibersihkan mata nanasnya lalu dicuci. Tahap selanjutnya dilakukan penghancuran buah menggunakan blender dengan penambahan air 4:1, kemudian dilakukan penyaringan sehingga diperoleh sari buah nanas. Sari buah nanas yang dihasilkan selanjutnya difermentasi dengan menggunakan empat kultur yang berbeda, Lactobacillus acidophilus, Lactobacillus bulgaricus, Lactobacillus casei, dan Streptococcu thermophilus dengan memodifikasi metode yang sudah ada, ${ }^{[9]}$ sehingga dihasilkan minuman fermentasi laktat sari buah nanas. Sebelum difermentasi, sari buah nanas ditambahkan susu skim steril sebanyak $10 \%(\mathrm{~b} / \mathrm{v})$ dan penambahan glukosa steril sebanyak $3 \% \quad(\mathrm{~b} / \mathrm{v}) . \quad$ Selanjutnya diinokulasi dengan kultur kerja L. acidophilus $4 \%(\mathrm{v} / \mathrm{v})$, L. bulgaricus $4 \%(\mathrm{v} / \mathrm{v})$, L. casei $4 \%$ (v/v), dan S. thermophylus $4 \%$ (v/v), kemudian diinkubasi pada suhu $37^{\circ} \mathrm{C}$.

\subsubsection{Pengujian Nilai $p H$}

Sebelum dilakukan pengukuran, $\mathrm{pH}$ meter harus dikalibrasi terlebih dahulu menggunakan larutan penyangga (buffer) 7,0. Selanjutnya dilakukan pengukuran terhadap larutan sampel dengan mencelupkan elektroda pada $\mathrm{pH}$ meter ke dalam larutan sampel dan biarkan beberapa saat sampai diperoleh pembacaan yang stabil.

\subsubsection{Pengujian Total Asam}

Sebanyak $1 \mathrm{~mL}$ sampel dimasukkan ke dalam erlenmeyer selanjutnya diencerkan dengan $10 \mathrm{~mL}$ air destilat, campuran tersebut kemudian dititrasi dengan larutan $\mathrm{NaOH} 0,1 \mathrm{~N}$. Untuk menentukan titik akhir titrasi digunakan indikator fenolftalin. Akhir titrasi tercapai setelah terbentuk warna merah muda yang konstan.

\subsubsection{Pengujian Total BAL}

Sebanyak $1 \mathrm{~mL}$ sampel dimasukkan ke dalam $9 \mathrm{~mL}$ larutan garam fisiologis steril. Dari campuran tersebut diperoleh pengenceran $10^{-1}$. Campuran kemudian dihomogenkan dan 
diambil $1 \mathrm{~mL}$ larutan dari tabung pertama dan dimasukkan ke dalam tabung reaksi berikutnya yang berisi $9 \mathrm{~mL}$ larutan garam fisiologis sehingga diperoleh pengenceran $10^{-2}$ dan seterusnya sampai diperoleh pengenceran yang sesuai $\left(10^{-8}\right.$ sampai dengan $\left.10^{-10}\right)$. Dari pengenceran yang dikehendaki diambil $1 \mathrm{~mL}$ sampel dengan pipet lalu dimasukkan ke dalam cawan petri steril, kemudian ditambahkan kirakira $15 \mathrm{~mL}$ media MRS Agar steril. Kemudian cawan diinkubasi pada suhu $37^{\circ} \mathrm{C}$ selama 48 jam dan dihitung koloni yang tumbuh menggunakan Colony Counter. Total koloni yang terhitung harus memenuhi standar International Comission Microbiology Food (ICMF) yaitu antara 30 sampai 300 koloni per cawan petri.

\subsubsection{Pengujian Ketahanan Terhadap Asam (pH 2,5)}

Pengujian ketahanan BAL yang terdapat dalam produk terhadap asam $(\mathrm{pH} 2,5)$ dilakukan dengan metode hitungan cawan. Dari masingmasing produk minuman fermentasi laktat dengan BAL yang berbeda diambil $1 \mathrm{~mL}$ lalu dimasukkan ke dalam $9 \mathrm{~mL}$ MRS Broth yang sudah diatur pada kondisi asam yaitu $\mathrm{pH}$ 2,5 dengan menambahkan $\mathrm{HCl}$ pekat. Sebagai kontrol, yaitu masukkan dalam jumlah yang sama namun MRS Broth tanpa penambahan HCl. Selanjutnya diinkubasi selama 24 jam pada suhu $37^{\circ} \mathrm{C}$. Setelah diinkubasi, diambil 1 $\mathrm{mL}$ sampel lalu dimasukkan ke dalam media pengenceran, dan dilakukan pengenceran hingga $10^{-6}$. Pada pengenceran $10^{-4}, 10^{-5}$ dan $10^{-6}$ diambil $1 \mathrm{~mL}$ dan dipindahkan ke dalam cawan steril lalu tambahkan media MRS agar steril lalu dihomogenkan dengan cara diputarputar membentuk angka 8 , kemudian cawan diinkubasi selama 24 jam pada suhu $37^{\circ} \mathrm{C}$. Ketahanan terhadap asam dihitung berdasarkan selisih unit log jumlah koloni yang tumbuh pada kondisi kontrol dengan perlakuan pengaturan $\mathrm{pH} 2,5$. Semakin kecil selisih antara jumlah koloni antara control dengan perlakuan asam maka semakin tahan galur BAL yang diuji terhadap $\mathrm{pH}$ rendah.

\subsubsection{Pengujian Aktivitas Antibakteri}

Pengujian aktivitas antibakteri dilakukan menurut prosedur berikut. ${ }^{[10]}$ Kultur bakteri uji
Bacillus cereus yang murni dari media NA Broth dipindahkan ke dalam tabung yang berisi medium cair steril NB, diikubasi selama 24 jam pada suhu $37^{\circ} \mathrm{C}$ dan dihomogenkan dengan vortex. Kultur tersebut diinokulasikan sebanyak $40 \mathrm{~L}$ ke dalam erlenmeyer yang telah berisi $60 \mathrm{~mL}$ media Nutrient Agar (NA) steril dengan suhu $44-45^{\circ} \mathrm{C}$, dihomogenisasi lalu dituang ke dalam empat cawan petri steril secara merata dan dibiarkan hingga membeku. Selanjutnya dibuat empat lubang (sumur) dalam setiap cawan secara aseptis dengan diameter yang seragam $6 \mathrm{~mm}$ dan dimasukkan $60 \mathrm{~L}$ produk minuman fermentasi laktat sari buah nanas. Sumur uji diinkubasi selama 48 jam pada suhu $37^{\circ} \mathrm{C}$ untuk diukur zona penghambatannya.

\section{HASIL DAN PEMBAHASAN}

\subsection{Total Asam Laktat}

Nilai total asam laktat pada minuman fermentasi laktat sari buah nanas yang menggunakan jenis BAL berbeda yaitu berkisar $2,0 \%-3,5 \%$, dan sebagai pembandingnya nilai total asam laktat pada minuman sari nanas tanpa pemberian BAL yaitu 1,2\%. Hasil uji lanjut BNT (Tabel 1) jenis BAL berbeda tidak nyata terhadap nilai total asam laktat minuman fermentasi laktat sari nanas. Namun nilai total asam laktat minuman fermentasi laktat sari nanas dengan jenis BAL Lactobacillus casei berbeda nyata dengan minuman sari nanas tanpa pemberian BAL (kontrol).

Tabel 1. Nilai tengah total asam minuman fermentasi laktat sari buah nanas

\begin{tabular}{lc}
\hline \multicolumn{1}{c}{ Perlakuan } & $\begin{array}{c}\text { Nilai tengah total } \\
\text { asam laktat }\end{array}$ \\
\hline Lactobacillus casei & $3,45 \mathrm{a} \pm 2,56$ \\
Lactobacillus acidophilus & $2,10 \mathrm{ab} \pm 0,52$ \\
Streptococcus thermophilus & $2,10 \mathrm{ab} \pm 1,30$ \\
Lactobacillus bulgaricus & $1,95 \mathrm{ab} \pm 0,94$ \\
Kontrol & $1,20 \mathrm{~b} \pm 0,52$
\end{tabular}

Keterangan: Notasi huruf yang sama menunjukkan perbedaan yang tidak nyata antar perlakuan (pada taraf $5 \%)$ 
Nilai total asam laktat yang tinggi ini disebabkan pada waktu inkubasi terjadi proses perombakan glukosa oleh BAL yang lebih lama dan optimal sehingga asam laktat yang dihasilkan pun semakin tinggi. Peningkatan aktivitas BAL dalam memecah laktosa akan menjadi asam laktat sebagai produk akhir metabolisme BAL. ${ }^{[1]}$ Menurut penelitian yan lain mengenai pembuatan minuman fungsional dari whey dangke bahwa perbedaan kandungan asam pada produk minuman fungsional whey dangke dipengaruhi oleh media fermentasi, jenis bakteri, dan lamanya inkubasi. ${ }^{[12]}$ Selain itu kandungan asam pada minuman fermentasi laktat sari nanas juga dipengaruhi oleh penambahan glukosa, dimana glukosa akan dipecah menjadi asam piruvat melalui jalur Embden Meyerhof-Parnas (EMP) menjadi asam laktat. $^{[13]}$

\subsection{Nilai pH}

Nilai $\mathrm{pH}$ pada minuman fermentasi laktat sari buah nanas dengan menggunakan jenis BAL berbeda Lactobacillus acidophylus (La), Lactobacillus bulgaricus (Lb), Lactobacillus casei, dan Streptococcus thermophylus (St) dalam penelitian ini secara berturut-turut adalah 3,42; 3,59; 3,54; dan 3,69, dan minuman sari nanas tanpa penggunaan BAL (kontrol) sebagai pembanding menunjukkan nilai $\mathrm{pH} \mathrm{4,00} \mathrm{(Tabel}$ 2).

Tabel 2. Nilai tengah $\mathrm{pH}$ minuman fermentasi laktat sari buah nanas

\begin{tabular}{lll}
\hline \multicolumn{1}{c}{ Perlakuan } & \multicolumn{2}{c}{ Nilai tengah pH } \\
\hline Lactobacillus acidophylus & 3,42 & $\mathrm{a} \pm 0,47$ \\
Lactobacillus casei & 3,54 & $\mathrm{a} \pm 0,40$ \\
Lactobacillus bulgaricus & 3,59 & $\mathrm{ab} \pm 0,23$ \\
Streptococcus thermophylus & 3,69 & $\mathrm{ab} \pm 0,48$ \\
Kontrol & 4,00 & $\mathrm{~b} \pm 0,05$
\end{tabular}

Keterangan: Notasi huruf yang sama menunjukkan perbedaan yang tidak nyata antar perlakuan (pada taraf $5 \%)$

Nilai pH pada minuman fermentasi laktat sari buah nanas dipengaruhi oleh kandungan asam laktat. Hasil uji BNT nilai pH (Tabel 1) memiliki pola yang sama dengan hasil uji BNT total asam laktat (Tabel 2). Sebagaimana pada hasil uji BNT total asam laktat, hasil uji lanjut BNT pada $\mathrm{pH}$ menunjukkan bahwa minuman fermentasi laktat sari buah nanas dengan menggunakan jenis BAL berbeda tidak nyata terhadap nilai $\mathrm{pH}$ minuman fermentasi laktat sari buah, tetapi nilai $\mathrm{pH}$ yang ditunjukkan oleh minuman fermentasi laktat sari buah nanas dengan BAL jenis Lactobacillus acidophylus dan Lactobacillus casei berbeda nyata terhadap nilai $\mathrm{pH}$ minuman sari nanas tanpa menggunakan BAL (kontrol) (Tabel 2). Pada Tabel 2 terlihat bahwa nilai $\mathrm{pH}$ antar minuman fermentasi sari nanas dengan penggunaan BAL berkisar antara 3,42 - 3,69 dan sebagai pembandingnya nilai $\mathrm{pH}$ minuman sari nanas tanpa pemberian BAL (kontrol) lebih tinggi yaitu 4,00 .

\subsection{Total Bakteri Asam Laktat}

Nilai total bakteri asam laktat (BAL) minuman fermentasi laktat sari buah nanas dengan menggunakan berbagai jenis $\mathrm{BAL}$ berkisar dari $1,1 \times 10^{10} \log \mathrm{koloni} / \mathrm{mL}$ hingga $3,2 \times 10^{10} \log \mathrm{koloni} / \mathrm{mL}$ atau setara dengan kisaran nilai $10^{10} \log$ koloni/mL (Tabel 3). Hasil analisis ragam dan uji BNT menunjukkan bahwa jenis BAL tidak berpengaruh nyata terhadap nilai total BAL minuman fermentasi laktat sari buah nanas. Artinya jenis BAL yang digunakan tidak mempengaruhi jumlah BAL dalam minuman fermentasi laktat yang dihasilkan.

Tabel 3. Nilai tengah total BAL minuman fermentasi laktat sari buah nanas

\begin{tabular}{lc}
\hline \multicolumn{1}{c}{ Perlakuan } & $\begin{array}{c}\text { Nilai tengah total bakteri } \\
\text { asam laktat }(\log \mathbf{x})\end{array}$ \\
\hline Streptococcus thermophilus & $10,51 \mathrm{a} \pm 0,22$ \\
Lactobacillus acidophilus & $10,41 \mathrm{a} \pm 0,10$ \\
Lactobacillus bulgaricus & $10,18 \mathrm{a} \pm 0,18$ \\
Lactobacillus casei & $10,04 \mathrm{a} \pm 0,12$ \\
\hline
\end{tabular}

Keterangan: Notasi huruf yang sama menunjukkan perbedaan yang tidak nyata antar perlakuan (pada taraf $1 \%)$ 
Perbedaan total BAL dari masing-masing minuman fermentasi laktat sari nanas dengan berbagai penambahan BAL dipengaruhi oleh ketersediaan substrat dalam media dan lama fermentasi. Sementara itu masing-masing bakteri asam laktat (BAL) memiliki waktu generasi yang berbeda-beda sehingga menyebabkan kemampuan fase log (adaptasi) bakteri pun berbeda-beda. Pertumbuhan koloni BAL pada penelitian ini juga dipengaruhi oleh kandungan gula pada sari buah nanas sebagai sumber karbon. Nanas memiliki kandungan gula sebesar 2,70\%.[14] Glukosa merupakan nutrisi penting untuk pertumbuhan BAL sebagai sumber energinya, sehingga adanya glukosa dapat memicu pertumbuhan koloni BAL dengan cepat dalam jumlah besar. ${ }^{[4]}$ Namun, karena semua faktor dalam media fermentasi sama, maka pertumbuhan BAL dalam media fermentasi selama inkubasi nampaknya juga tidak menunjukkan aktivitas yang berbeda, sehingga jumlah BAL dalam produk sama.

Hasil analisis total BAL minuman fermentasi laktat sari buah nanas dengan penambahan BAL pada penelitian ini menunjukkan kisaran 10,04 log koloni/mL hingga $10,51 \log$ koloni/mL atau setara dengan $10^{10} \mathrm{koloni} / \mathrm{mL}$. Standar Nasional Indonesia SNI 7552: 2009 menyatakan syarat minimum nilai total BAL yang baik ialah sebanyak $10^{6}$ $\mathrm{kol} / \mathrm{mL} .^{[15]}$ Syarat dari suatu produk dikatakan probiotik apabila produk tersebut mengandung total BAL yang masih hidup pada saat dikonsumsi $\geq 10^{6} \mathrm{cfu} / \mathrm{mL}$. Berdasarkan hasil penelitian, maka nilai total BAL minuman fermentasi laktat sari nanas telah memenuhi standar minuman fermentasi laktat.

\subsection{Ketahanan Terhadap Asam}

Pengujian ketahanan terhadap asam dilakukan untuk mengetahui apakah minuman fermentasi laktat sari buah nanas ini memenuhi kriteria sebagai produk probiotik. Pada penelitian ini pengujian ketahanan berbagai jenis BAL dalam masing-masing minuman fermentasi laktat sari buah nanas yang dihasilkan dilakukan pada $\mathrm{pH}$ rendah yaitu 2,5. Selisih log jumlah koloni BAL dalam minuman fermentasi laktat sari buah nanas yang diberi perlakuan asam ( $\mathrm{pH}$ 2,5) dengan log jumlah BAL dari produk kontrol (tanpa penurunan $\mathrm{pH}$ ) berkisar dari 5,67 log koloni/mL hingga 6,03 $\log \mathrm{koloni} / \mathrm{mL}$ sampel atau setara dengan $10^{5}$ hingga $10^{6}$ (Tabel 4). Nilai tersebut didapat dari selisih total BAL minuman fermentasi laktat sari buah nanas tanpa pemberian perlakuan asam dan total BAL minuman fermentasi laktat sari buah nanas yang diberi perlakuan asam. Nilai selisih tersebut menunjukkan jumlah BAL yang mengalami kematian. Semakin kecil nilai selisih total BAL maka semakin tahan terhadap kondisi asam rendah yang berarti lebih berpotensi sebagai probiotik.

Tabel 4. Nilai tengah hasil pengujian ketahanan terhadap asam minuman fermentasi laktat sari buah nanas

\begin{tabular}{lc}
\hline \multicolumn{1}{c}{ Perlakuan } & $\begin{array}{c}\text { Nilai tengah selisih } \log \\
\text { koloni }(\log \mathbf{x})\end{array}$ \\
\hline Lactobacillus casei & $5.67 \mathrm{a} \pm 0,41$ \\
Lactobacillus acidophylus & $5,69 \mathrm{a} \pm 0,23$ \\
Lactobacillus bulgaricus & $5,89 \mathrm{a} \pm 0,21$ \\
$\begin{array}{l}\text { Streptococcus } \\
\text { thermophylus }\end{array}$ & $6,03 \mathrm{a} \pm 0,47$ \\
\hline
\end{tabular}

Keterangan: Selisih jumlah koloni merupakan indikasi ketahanan BAL terhadap asam, makin kecil nilai selisihnya makin tahan terhadap asam. Notasi huruf yang sama menunjukkan perbedaan yang tidak nyata antar perlakuan (pada taraf 5\%)

\section{Hasil uji lanjut BNT (Tabel 4)} menunjukkan semua minuman fermentasi laktat sari buah nanas dengan berbagai jenis BAL memiliki ketahanan yang baik untuk tumbuh pada kondisi asam ( $\mathrm{pH}$ rendah) dan tidak terdapat perbedaan yang nyata pada ketahanan terhadap asam minuman fermentasi laktat dengan berbagai jenis BAL yang sudah diuji. Minuman fermentasi laktat sari nanas dengan penambahan BAL dari jenis Lactobacillus selisih jumlahnya lebih kecil dibandingkan dari jenis Streptococcus. Hasil tersebut sejalan dengan beberapa penelitian yang menunjukkan bahwa bakteri asam laktat terutama golongan laktobasili termasuk bakteri yang paling tahan terhadap kondisi asam. ${ }^{[16]}$ Hasil uji ketahanan 
terhadap asam pada penelitian ini mencapai $10^{5}$ $\mathrm{cfu} / \mathrm{mL}$, dimana pada uji ketahanan terhadap asam pada minuman fermentasi laktat sari buah nanas ini, populasi BAL masih memenuhi syarat minuman fermentasi laktat. Bakteri probiotik mempunyai efek pada lingkungan usus apabila jumlah populasi dari bakteri tersebut mencapai minimal $10^{6}-10^{8} \mathrm{cfu} / \mathrm{mL}$ di dalam usus. ${ }^{[17]}$

\subsection{Aktivitas Antibakteri}

Kriteria lain suatu minuman dapat dikategorikan sebagai produk probiotik adalah kemampuannya sebagai antibakteri. Pengukuran aktivitas antibakteri minuman fermentasi laktat sari buah nanas ini dilakukan menggunakan metode difusi agar. Semakin besar zona hambat yang dihasilkan semakin tinggi aktivitas antibakteri minuman fermentasi yang diuji. Bakteri uji pada pengujian aktivitas antibakteri ini adalah Bacillus cereus. Hasil penelitian menunjukkan data luas zona hambat minuman fermentasi sari buah nanas dengan berbagai jenis BAL yang digunakan terhadap bakteri uji Bacillus cereus adalah 4,48 - 13,97 $\mathrm{mm}^{2}$. Hasil analisis ragam menunjukkan bahwa jenis BAL pada minuman fermentasi laktat sari buah nanas berpengaruh nyata terhadap aktivitas antibakteri uji Bacillus cereus. Hasil uji lanjut BNT dapat dilihat pada Tabel 5.

Tabel 5. Nilai tengah aktivitas antibakteri minuman fementasi laktat sari buah nanas terhadap Bacillus cereus

\begin{tabular}{lc}
\hline \multicolumn{1}{c}{ Perlakuan } & $\begin{array}{c}\text { Nilai tengah luas } \\
\text { zona hambat }\left(\mathbf{m m}^{2}\right)\end{array}$ \\
\hline Lactobacillus casei & $13,97 \mathrm{a} \pm 2,55$ \\
Lactobacillus bulgaricus & $9,57 \mathrm{ab} \pm 6,4$ \\
Lactobacillus acidophilus & $8,52 \mathrm{abc} \pm 8,17$ \\
Streptococcus thermophylus & $4,48 \mathrm{bc} \pm 2,56$ \\
Kontrol & $1,56 \mathrm{c} \pm 1,42$ \\
\hline
\end{tabular}

Keterangan: Notasi huruf yang sama menunjukkan perbedaan yang tidak nyata antar perlakuan (pada taraf 5\%). Nilai aktivitas minuman dengan penggunaan BAL sudah dikurangi dengan nilai aktivitas yang dihasilkan oleh minuman sari nanas tanpa pemberian BAL (kontrol)
Tabel 5 menunjukkan hasil uji BNT bahwa jenis BAL Lactobacillus casei minuman fermentasi laktat sari buah nanas berbeda nyata terhadap nilai aktivitas antibakteri Bacillus cereus minuman sari buah nanas dengan jenis BAL S. thermophilus dan terhadap minuman sari nanas tanpa pemberian BAL. Namun berbeda tidak nyata dengan nilai aktivitas antibaktei yang dihasilkan oleh minuman fermentasi laktat sari buah nanas dengan penggunaan L. bulgaricus, dan L. acidophilus.

Pada pengujian aktivitas antibakteri terhadap Bacillus cereus, minuman fermentasi laktat sari buah nanas dengan menggunakan bakteri Lactobacillus casei menunjukkan aktivitas penghambatan yang terbesar, yaitu $13,97 \mathrm{~mm}^{2}$. Dari hasil tersebut terlihat bahwa aktivitas antibakteri terhadap bakteri patogen oleh minuman fermentasi laktat sari buah nanas dengan berbagai jenis BAL ternyata menunjukkan derajat penghambatan yang sama. Namun penghambat yang baik berasal dari minuman dengan jenis BAL Lactobacillus casei. Hal ini diduga karena bakteri golongan laktobasili, khususnya Lactobacillus casei termasuk jenis BAL homofermentatif, yaitu golongan bakteri yang hanya memfermentasi glukosa menjadi asam laktat sebagai produk utamanya dalam jumlah yang besar $(90 \%) .{ }^{[18]}$

Selain asam laktat, bakteri ini juga menghasilkan asam sitrat, malat, suksinat, asetaldehid, diasetil dan asetoin dalam jumlah yang kecil. Asam laktat dan asam organik lain yang diproduksi oleh bakteri ini dapat menghambat aktivitas bakteri patogen. ${ }^{[18]}$ Selain itu juga kandungan antioksidan dalam buah nanas yang bersifat sebagai antibakteri dapat menghambat pertumbuhan mikroba patogen. ${ }^{[19]}$

Kemampuan minuman fermentasi laktat sari buah nanas yang dibuat dengan menggunakan berbagai jenis BAL, baik Lactobacillus acidophilus, Lactobacillus bulgaricus, Lactobacillus casei, dan Streptococcus thermophilus untuk menghambat bakteri uji (Bacillus cereus) menunjukkan bahwa minuman fermentasi laktat sari buah nanas berpotensi sebagai minuman probiotik. Hal ini juga diperkuat dengan daya tahan BAL 
dalam produk terhadap kondisi asam (pengujian ketahanan asam pd $\mathrm{pH}$ 2,5).

\subsection{Penentuan Perlakuan Terbaik}

Dari hasil uji potensi probiotik yang sudah dilakukan (nilai $\mathrm{pH}$, total asam, total BAL, ketahanan terhadap asam, aktivitas antibakteri) terhadap minuman fermentasi laktat sari buah nanas dengan berbagai jenis BAL, Lactobacillus casei menunjukkan aktivitas antibakteri yang terbesar terhadap bakteri patogen indikator (Bacillus cereus), ketahanan yang baik terhadap asam, dan total BAL yang tinggi. Oleh karena itu Lactobacillus casei dianggap sebagai perlakuan terbaik dalam menghasilkan minuman probiotik sari buah nanas yang terbaik. Hal ini sejalan dengan hasil penelitian sebelumnya yang menyatakan bahwa daya hambat susu probiotik yang diproduksi dengan Lactobacillus casei lebih besar dibandingkan susu probiotik Lactobaciluus acidophilus. ${ }^{[2]}$

\section{KESIMPULAN}

Lactobacillus casei terpilih sebagai perlakuan terbaik yang menghasilkan minuman fermentasi laktat sari buah nanas dengan selisih log ketahanan terhadap asam terkecil yaitu 5,67 $\log$ koloni/mL; serta nilai aktivitas antibakteri terbesar terhadap Bacillus cereus yaitu 13,97 $\mathrm{mm}^{2}$. Sebagai minuman probiotik terbaik, minuman fermentasi laktat sari buah nanas dengan Lactobacillus casei memiliki karakteristik pH 3,54; total asam sebesar 3,45; total bal sebesar $1,1 \times 10^{10} \log$ koloni/mL.

\section{UCAPAN TERIMA KASIH}

Ucapan terimakasih disampaikan kepada Kementerian Riset, Teknologi dan Pendidikan Tinggi dan LPPM Universitas Lampung yang telah mendanai dan menfasilitasi penelitian ini melalui skim Hibah Bersaing Dana BOPTN tahun 2015.

\section{DAFTAR PUSTAKA}

Accreditation number : 540/AU1/P2MI LIPI/06/2013

[1] E. Herlina, dan F. Nuraeni. "Pengembangan Produk Pangan Fungsional Berbasis Ubi Kayu (Manihot esculenta) dalam Menunjang Ketahanan Pangan”, Jurnal Sains Dasar, vol. 3 (2), pp. 142-148, 2014.

[2] Rusilanti. "Aspek Psikososial, Aktivitas Fisik, Konsumsi Makanan, Status Gizi dan Pengaruh Susu Plus Probiotik Enterococcus faecium IS-27526 (MEDP) terhadap Respons Imun IgA Lansia." disertasi, GMK, Sekolah Pascasarjana, IPB, Bogor, 2006.

[3] Vedamuthu. Fermented Foods. London: Academic Press, 1982.

[4] S. Rizal, S. Udayana, dan Marniza. "Pengaruh Penambahan Glukosa dan Skim pada Pembuatan Minuman Laktat Sari Kulit Nanas yang Difermentasi oleh Lactobacillus acidophilus". Jurnal AGRITEK, ISSN 0852-5426, vol. 15 (1), Feb. 2007.

[5] A.S. Suharyono, S. Rizal, dan F. Nurainy. "Karakteristik Minuman Sinniotik dari Ekstrak Daun Cincau Hijau (Premna oblongifolia Merr.) dengan Konsentrasi Sukrosa dan Susu Skim yang Berbeda. Prosiding Seminar Nasional Sains MIPA dan Aplikasinya 2009, vol. 1, pp. 16-17, 2010.

[6] K. Khotimah dan J. Kusnadi. "Aktivitas Antibakteri Minuman Probiotik Sari Kurna (Phoenix dactilyfera, L.) Menggunakan Lactobacillus plantarum dan Lactobacillus casei”. Jurnal Pangan dan Agroindustri, vol 2 (3), pp. 110-120, Jul. 2014.

[7] E.P. Oktaviani, L.M.E. Purwijantiningsih, dan F.S. Pranata. (2014). "Kualitas dan aktivitas antioksidan minuman probiotik dengan variasi ekstrak buah naga merah (Hyloreceus polyrhizus)". http://e-journal. uajy.ac.id/6526/1/JURNAL.pdf

[8] S. Rizal dan F. Nurainy. "Perbaikan Kualitas Minuman Fermentasi Laktat dari Buah Nanas (Ananas muricata) sebagai Minuman Probiotik yang Bersifat Antimikroba dan Antioksidan," Laporan 
Penelitian Hibah Bersaing. Universitas Lampung. Indonesia, Nov. 2015.

[9] F. Nurainy, S. Rizal, dan Suharyono. "Evaluasi Pengaruh Sifat Probiotik, Status Antioksidan dan Stabilitas Penyimpanan Untuk Produksi Minuman Sinbiotik Antioksidan dari Ekstrak Cincau Hijau (Premnaoblongifolia Merr)," Laporan Hasil Penelitian Hibah Bersaing BOPTN, Universitas Lampung, Indonesia, Nov. 2013.

[10] Murhadi. "Ekstraksi, Fraksinasi, dan Identifikasi Komponen Antibakteri Biji Atug (Parinarium glaberrimum Hask)." Buku Monograf (ISBN 978-979-8510-083), Penerbit Lembaga Penelitian Universitas Lampung, Bandarlampung, 2009.

[11] B. Misrianti. "Pengaruh Penambahan Sukrosa pada Pembuatan Whey Kerbau Fermentasi Terhadap Penghambatan Bakteri Patogen." Skripsi, Fakultas Peternakan, Universitas Hasanudin. Makasar, 2013.

[12] Fatma. "Potensi dan Perkembangan Whey Dangke Menjadi Minuman Fungsional." Desertasi, Program Pascasarjana Fakultas Peternakan Universitas Gadjah Mada, Yogyakarta, 2012.

[13] B.H. Lee. Fundamental of Food Biotechnology, New York: VCH Publishers. Inc., 1996.

[14] M.S. Asiedu, W. Wardy, F.K. Saalia, A.S. Budu dan S.S. Dedeh. "A comparison of some physical, chemical and sensory attributes of three pineaple (Ananas cosmosus) varieties grown in Ghana". African Journal of Science, vol. 3(1), pp. 022-025, 2009.

[15] Badan Standarisasi Nasional. SNI 7552:2009. Minuman Susu Fermentasi Berperisa, Jakarta: Badan Standarisasi Nasional, 2009.

[16] J.B. Russel dan Diaz-Gonzales. Lactic Acid Bacteria, New York: Marcel Dekker, 1998.
[17] H. Kimoto, J. Kurisaki, M. Tsuji, S. Ohmono, T. Okamoto. "Lactococci as probiotic strain: adhesion to human enterocyte-like caco-2 cells and tolerance to low $\mathrm{pH}$ and bite." Lett Appl Microbiol vol. 29, pp. 313-316, 1999.

[18] M.L. Speck. Development in Industrial Microbiology, Economic Microbiology Fermented Food Vol. VII, London: Academic Press, 1978.

[19] N. Daniswara. Perbandingan Efektivitas Air Perasan Buah Nanas (Ananas comosus (L.) Merr) 100\%, Zinc Pyrithione $1 \%$ dan Ketokonazol $1 \%$ secara in vitro terhadap Pertumbuhan Pityrosporum ovale, Artikel Karya Tulis Ilmiah, Semarang: Fakultas Kedokteran Universitas Diponegoro, 2008.

[20] N. Nelinton, Isnaeni, dan N.E. Nasution. "Aktivitas Antibakteri Susu Probiotik Lactobacilli Terhadap Bakteri Penyebab Diare (Escherichia coli, Salmonella typhimurium, Vibrio cholerae)." Jurnal Farmasi dan Ilmu Kefarmasian Indonesia, vol 2 (1), pp, 25-30. Juni 2015. 
J.Kim.Terap.Indones., 18(1),

pp. 63-71, June 2016
p-ISSN: 0853-2788, e-ISSN: 2527-7669 Accreditation number : 540/AU1/P2MI LIPI/06/2013

Halaman ini sengaja dikosongkan

This page intentionally left blank 